M. Tepliuk ${ }^{\mathbf{1}}$, orcid.org/0000-0001-6823-336X, T. Shkoda ${ }^{1}$, orcid.org/0000-0003-1016-4853, V. Kukoba', orcid.org/0000-0003-3107-6000, T. Chebakova ${ }^{1}$, orcid.org/0000-0002-0370-4981, S. Petrovska ${ }^{2}$, orcid.org/0000-0001-5354-1343
1 - Kyiv National Economic University named after Vadym Hetman, Kyiv, Ukraine, e-mail: mteplyuk@gmail.com 2 - National Aviation University, Kyiv, Ukraine

\title{
ORGANIZATIONAL CULTURE IN COOPERATION OF BUSINESS AND EDUCATION IN UKRAINE
}

Purpose. To improve a method of organizational culture assessment for making management decisions in cooperation of business and education.

Methodology. The study is based on the data of the leading enterprises producing plastics in Ukraine over the period of 2015-2019. Through the method of binary logic for the purposes of assessing the proposed components of organizational culture of enterprises (intellectual, technical-technological, social, legal and regulatory, professional, communicative, informational), the levels of this culture in plastics manufacturers are determined in mathematical terms.

Findings. Based on the generalization of the results of theoretical research on the economic essence of the organizational culture of the enterprise, its key components and the main parameters characterizing them are identified. Public JSC "Ukrplastic" is identified as the leading company producing plastic products in Ukraine with the highest performance in organizational culture by individual components of the enterprise. The other analyzed companies have medium level of organizational culture indicators.

Originality. The research is conducive to the studies on organizational culture, especially the perspective of its usage as a tool of cooperation between Ukrainian plastic producers as the business representatives and educational sector.

Practical value. The results of the study can be used by practitioners, scientists, government officials (Ministry of Education and Science of Ukraine and its structural departments, local governments in the fields of education and science) to monitor the development of the information economy.

Keywords: organizational culture, cooperation, business, education, plastic producers, Ukraine

Introduction. Modern transformations in the economy of Ukraine most often relate to structural changes in industry. The contradiction of world economic processes in the context of globalization and development of the information society is manifested in qualitative large-scale transformations that make it impossible to use established factors of economic development, promote the widespread use of innovative strategies and unique technologies, in particular in the system of management. Changes create new organizational challenges and improve the organizational culture of the enterprise. Managers can develop organizational culture [1] influencing the employees' creativity, designing project groups, creating the appropriate motivational climate, and so on. The organization of the internal environment of companies is increasingly associated with the formation of organizational culture as the best approach to ensuring cooperation of business and education with the help of effective involvement of employees and adaptation of the firm to the external environment. That is why the formation and development of the latest theoretical and methodological foundations of organizational culture and, in particular, business culture of the enterprise becomes relevant.

Literature review. The basis of sustainable development of the global economy has always been the dynamic and balanced development of efficient and competitive enterprises. An enterprise is considered efficient and competitive if it has a stable financial position and uninterrupted profitability, regardless of competitive fluctuations in the environment where the enterprise operates. However, the efficiency of the enterprise is also significantly influenced by such factors of entrepreneurial activity as the technologies used by the enterprise, the qualification of its personnel, available financial resources, and so on. All these factors, in turn, depend on the ability of participants of the enterprise, rational use of available resources and effi-

(C) Tepliuk M., Shkoda T., Kukoba V., Chebakova T., Petrovska S., 2021 cient performance of business processes, which largely depends on the rules and norms of relations between the participants of the enterprise. And these rules and regulations form the basis of intra-firm culture, which is often called organizational culture [2]. The evolution of technology, the so-called digitalization in the economy on modern households has contributed to the transformation and transition of organizational culture from secondary factors of production to the category of strategic resources of the company.

The results of scientific research indicate $[3,4]$ the existence of a number of prerequisites for the development of organizational culture, the essence of which is the emergence of levers of change in the modern economic paradigm and the exceptional importance of organizational culture to ensure sustainable development of enterprises. Various aspects of organizational culture, especially those of business entities have been studied by scholars for a long time $[5,6]$ but still the role and place of organizational culture in general and in industrial relations of business entities in particular remain insufficiently covered.

The study on the phenomenon of organizational culture is to determine the important role of key management factors, most of which have no material form and indirectly affect the economic performance of economic entities [7]. Such factors include internal relationships and communications, image, leadership style, brand, principles and mission of the enterprise and so on. Despite the indirect reflection of the effective ordering of the organizational culture of the enterprise on the economic indicators of the organization, the nature of the impact is significant, but delayed in time.

Recently, more and more scholars $[8,9]$ have begun to pay attention to the culture in the organization, more and more publications on this problem [10] appear in the scientific literature, but it is still not clear what "organizational culture" and "business culture" are, what the difference between these two terms is, and which varieties it has. Therefore, first of all it 
is necessary to form evaluation characteristics, indicators, norms and methods of evaluation of organizational culture. To do this, the authors have to define firstly what "organizational culture", and "business culture" are and form the concept of "organizational culture".

The variety of theoretical concepts that affect aspects of organizational culture in the enterprise is mainly consolidated within the theories of management. The scientific research studies [11, 12] prove the indisputable importance of organizational culture in the process of intensifying the activities of enterprises, which provides an increase in their competitiveness.

Organizational culture is characterized by compliance with corporate governance principles in particular, which means that it is necessary to pay attention to the fact of corporate governance or internal corporate code, regulations on corporate culture and business culture at the firm, the company's image and appropriate management measures for its formation and development.

Effective management is based on the organizational culture of the enterprise as a factor of economic growth, influence on management decisions, introduction of innovative technologies, rational use of means of labor and production, saving time, increasing competitiveness and labor productivity. Based on this, the management system provides a solid foundation for long-term and sustainable development, and the key aspect is values and principles [13] that are comprehensive in nature and stable. The value-oriented nature of the management system ensures the supply to the external environment of not only goods and services, but also of certain values of social responsibility to employees, consumers, workers, managers, owners, society, and environment. One of the important marketing components is the company's brand, which in a fixed form characterizes and represents its values and mission.

The term "business culture" is very similar to the term "organizational culture", as the main difference between these terms is in the following: organizational culture differs from country to country and can be considered as business culture depending on a set of rules applying to people's behavior in social and official communication [14]. That is why, the communicative component is very important in developing the methodology of organizational culture evaluation. Interrelation of organizational culture, corporate culture and business culture is represented in Fig. 1.

The following factors contribute to the growing influence of organizational culture in ensuring effective management of enterprises producing plastic and metal products in Ukraine: 1) the presence of significant financial problems at a significant number of enterprises, which suspends modernization, automation of fixed assets, prevents the purchase of know- how, patents, copyright certificates hence the need to find alternative internal factors of development that do not require significant financial injections; 2) integration of Ukraine into the world economic space, whose characteristic feature is the widespread use of the doctrine of organizational culture in the practice of enterprise management.

According to the authors' point of view, organizational culture should also be considered as a tool for cooperation between business (entrepreneurial structures) and education (educational institutions, such as higher education institutions (HEIs)). Such possibility to use organizational culture as the tool of transferring training with the help of motivation was considered by [15] as a perspective for higher educational organizations. University scientists are also considered by the researchers [16] as contact audience of the marketing business network.

In addition, such cooperation occurs in the process of interaction, where each party is a stakeholder of the other. Some researchers believe $[17,18]$ that modern cooperation between an educational institution and a company is socially responsible. This is also confirmed by a set of parameters defined by the authors to assess the organizational culture of the company. In particular, the company's ability to interact with each other and with other professionals is part of the communicative component of organizational culture assessment parameters, and employee education is crucial for assessing the professional component of organizational culture.

Unsolved aspects of the problem. The constantly changing business environment and cooperation with universities require a revision of the synergy processes of the "business education" model. The authors propose the working hypotheses of the research:

$H 1$ - the communicative component as business culture reflection dominates among the other components of the organizational culture of the enterprises-manufacturers of plastic products and has a positive impact on its development;

$\mathrm{H} 2$ - cooperation of business and education in the plastic products industry is better when the organizational culture of the enterprises-manufacturers of plastic products is well developed.

The purpose of the article is to develop an innovative method of organizational culture assessment, which can be used for making management decisions in cooperation of business and education.

Methods. The study is based on the data of the leading enterprises producing plastics in Ukraine over the period of 2015-2019. Applying the method of binary logic for the purposes of assessing the proposed components of organizational culture of enterprises (intellectual, technical-technological, social, legal and regulatory, professional, communicative, in-

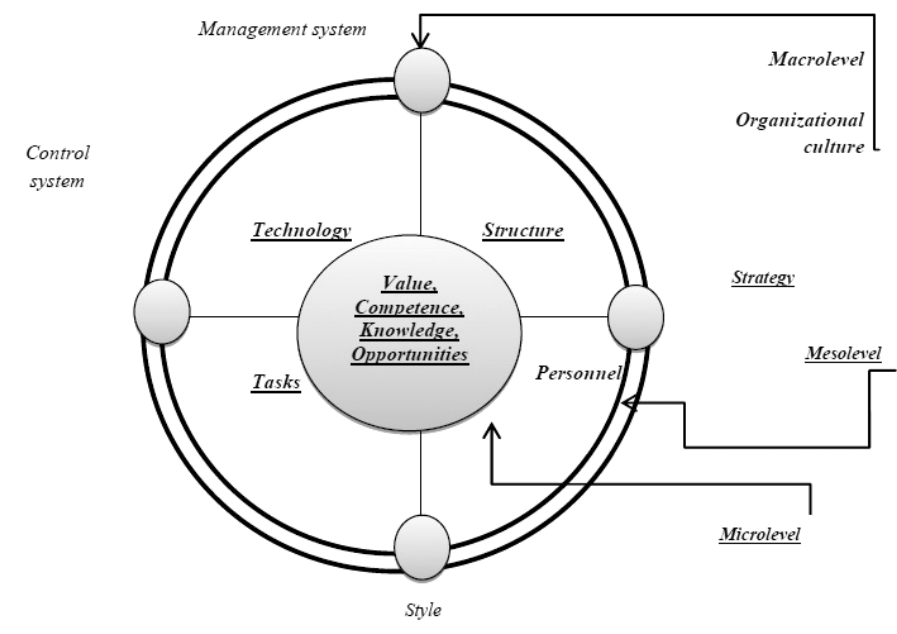

Fig. 1. Interrelation of organizational culture, corporate culture and business culture 
formational), the authors determine the levels of this culture in plastics manufacturers in mathematical terms. To develop and test a comprehensive methodological approach to assessing the impact of the research component on the development of the information economy based on the combination of statistical, index and cluster methods of analysis. Currently, the functioning of enterprises is significantly influenced by the results of their activities by ways of using production capacity, technology, personnel, financial and intellectual resources. However, it should be noted that one of the most meaningful factors is organizational culture and, in particular, business culture, which acts as a system that includes regulations, rules and values of behavior that determine the interaction and consistency of team members, management, departments, creating new innovative products, manufacturing, provision of services, provision of their own activity, relations of social responsibility, financial and economic relations and key factors of development of the enterprise.

At the industrial enterprises there is no proper justification for the relationship between the state of organizational culture and the level of efficiency of the enterprise, there is no clear methodology for forming the culture of organizations, corporate culture and business culture of the enterprise. The problem of building organizational culture as a foundation for improving the efficiency of the enterprise is extremely important. This should take into account not only the financial, intellectual and material resources of the enterprise, but also the business culture of the enterprise and its level.

That is why it is important to determine the parameters of the organization-enterprise regarding the formation of an evaluation system of organizational culture with its indicators, calculation methods, economic and mathematical models and ways of interpreting the results of modelling or current evaluation.

Organizational culture has a certain structure as an environment of values, norms, positions, beliefs, convictions of a group of people and the means by which these values are transmitted (through ritual, legends, and so on) to employees [19]. Effective reform of the executive and local government requires a clear understanding of the differences between traditional and desirable cultures. Exploring the culture of a public institution in transition [20], we identified five main provisions, on which the difference between the established old culture and the desired new one is based: sectoral context; consumer orientation; orientation of labor; motivation; human orientation.

Therefore, first of all, it is necessary to be defined with parameters which should be estimated. Since these parameters have different objects of evaluation, it is advisable to combine them into certain groups - sets (Fig. 2): a set of indicators for evaluating the professional component of organizational culture, a set of evaluation of its intellectual component, a set of evaluation of information, social, legal and regulatory, techni- cal and technological, and communicative components of the organizational culture of the business entity. Each of these sets has its own specific indicators and calculation formulas based on binary logic [19], which were taken as the basis of this research and improved by the authors.

To establish the reasons for the insufficient level of indicators for individual components of business culture, it is advisable to conduct a horizontal analysis at the level of primary evaluation indicators (PRFi (professional), ITCj (intellectual), INFk (informational), SOCm (social), LWIp (legal and regulatory), TECHq (technical and technological), $\mathrm{COMr}$ (communicative)), determining them by groups, departments or categories of personnel. The most objective estimates of the change in the level of business structure by its components can be obtained by establishing relationships between the values of these indicators and indicators of performance (or efficiency) of the firm's personnel. These relationships should establish the degree of relationship between the results obtained, management decisions and the levels of values of the calculated indicators in terms of components of business culture. The most informative in such manipulations will be a way to compare the rates of increase in the level of the component of business culture and increase the cost of its provision. In formalized form, this may have the following representation

$$
I_{B C L-E F}=\frac{I_{B C L}}{I_{E F}} \frac{\frac{O C L_{\text {after }}}{O C L_{\text {before }}}}{\frac{C O S T_{\text {before }}}{C O S T_{\text {after }}}},
$$

where $I_{O C L-E F}$ is the index of the rate of increase in the level of organizational culture of the firm; $I_{O C L}$ is the index of change in the level of organizational culture of the firm; $I_{E F}$ is the index of changes in costs for the formation of components of the business structure of the firm; $O C L_{a f t e r}$ is the indicator of the level of organizational culture of the company after the implementation of packages of works on the formation (development) of organizational culture of the firm; $O C L_{\text {before }}$ is the indicator of the level of organizational culture of the company before the implementation of packages of work on the formation (development) of organizational culture of the company; $C O S T_{\text {affer }}$ is the amount of current costs to ensure the current level of organizational culture after the implementation of packages of works on the development of organizational culture of the firm; $C O S T_{\text {before }}$ is the amount of current costs to ensure the current level of organizational culture before the implementation of work packages for the development of organizational culture of the firm.

It should be borne in mind that with $I_{O C L-E F}>1$ there is an effective increase in the firm's own level of organizational culture, and with $0<I_{O C L-E F}<1$ there is inefficient investment in the development of its own organizational culture, which re-

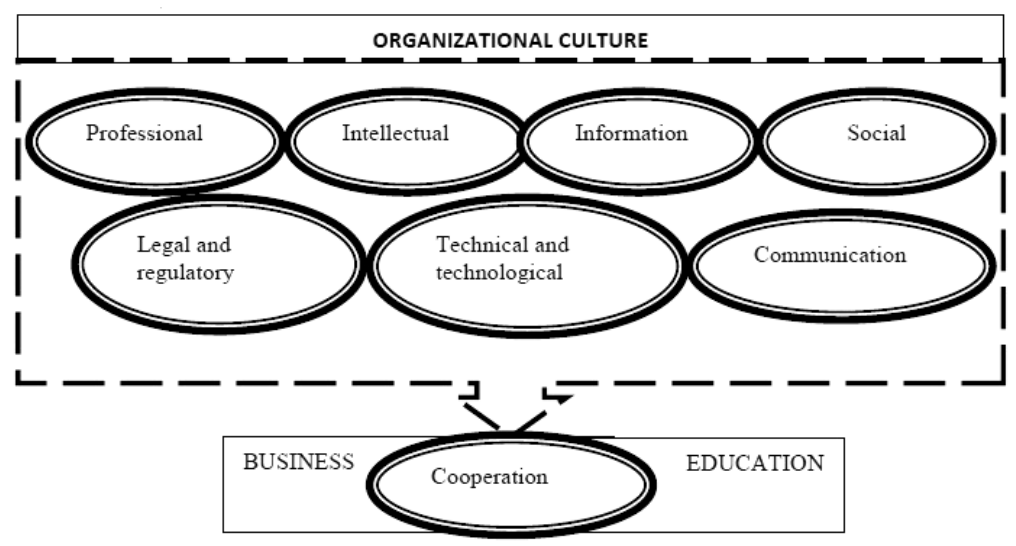

Fig. 2. Cooperation tool of business and education 
quires revision of work packages for further organizational and cultural transformation of the business entity [19].

Results. The proposed improved method of quantitative assessment of the level of organizational culture of companies in its form and approaches to determining the parameters of organizational culture is fundamentally different from existing ones in that it focuses on identifying and differentiated calculation of organizational culture parameters of firms and allows establishing causal links with organizational culture and the effectiveness of the functioning of economic entities. Through this method, the parameters of the components of organizational culture were calculated for nine enterprises-manufacturers of plastic products in Ukraine (Table). This allowed determining the differentiated levels of parameters of this culture for each of the selected group of companies, as well as assessing the degree of development of internal corporate relations that have formed in these enterprises. To determine the areas of activity in enterprises for which it is advisable to form their own differentiated culture of activity, it is advisable to consider the value of local indicators that characterize the degree of orderliness of activities in accordance with certain components of organizational culture of enterprises. According to local indicators that characterize the professional element of the organizational culture of the companies, the highest levels have Public JSC "Ukrplastic" (0.41) and LLC "Teplomash" (0.39), with the lowest value of this indicator in Private JSC "Budplastic" (0.30). This indicates that in all enterprises, the personnel selection is carried out in accordance with the requirements of technological processes of production, but small attention is paid to the training of personnel.

The intellectual component of the organizational culture of the enterprise is characterized by such indicators and has the maximum value in Private JSC "Household and industrial chemical plant"(0.32), Public JSC "Ukrplastic" (0.33), and the minimum value in Private JSC "Brovary Plastics Plant" (0.22), LLC "ITEM-Detail" (0.28). It can be concluded that at the enterprises producing plastic products, the level of the intellectual component is rather low, which testifies to insufficiently high education of personnel, low level of qualification of workers and lack of personnel policy.

Leaders in the informational component of the organizational culture of the enterprise became - Private JSC "Brova- ry Plastics Plant" and LLC "ITEM" both have -0.25 , Public JSC "Ukrplastic" -0.27 , occupy the lowest positions Private JSC "Plastmodern" (0.17), Private JSC "Household and industrial chemical plant" (0.19). The level of indicators for this component is low - this indicates a lack of reliable and appropriate information, which makes it impossible to apply the strategy of continuous innovation.

According to the social component of the organizational culture of the enterprise Private JSC "Zdolbuniv Plastic Products Plant "Iskra" (0.25), Public JSC "Ukrplastic" $(0.28)$ occupy the highest level and Private JSC "Plastmodern" (0.19), LLC "ITEM" (0.18), LLC "Planet plastic" (0.17) occupy the lowest level. Under the social component, the authors consider activities aimed at improving the personnel working conditions, which are able to motivate employees to increase their own level of competitiveness and productivity. Enterprises with low levels of organizational culture should soon take measures to activate the human factor, where work should be carried out taking into account not only organizational and technical aspects, but also socio-psychological ones that correspond to the modern development of social relations, biological features of human development, the stages of their life cycle. In this context, the economic component of organizational culture should be considered exclusively as a component of social policy.

Indicators of the legal and regulatory component of the organizational culture of the enterprise have their leaders, which are Private JSC "Plastmodern" (0.26) and Public JSC "Ukrplastic" (0.30), and "outsider" LLC "ITEM" (0.16). Since the legal and regulatory component is an organizational and functional image of the system of local self-government in the enterprise, it should be noted that this system has very low performance. This indicates that the legal and regulatory component is not provided with appropriate instructional and methodological materials and tools at the level of relevant departments. It is possible to increase the indicators by improving the relevant local regulations at the enterprise level.

The technical and technological component of the organizational culture of the enterprise distinguishes such leaders LLC "Planet plastic" (0.38), Public JSC "Ukrplastic" (0.43), such enterprises have the lowest indicators Private JSC "Household and industrial chemical plant" (0.21), Private

The level of organizational culture at the enterprises-manufacturers of plastic products (as of 15.07.2020)

\begin{tabular}{|c|c|c|c|c|c|c|c|c|c|c|}
\hline Indicators & 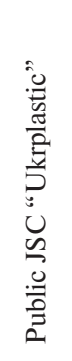 & 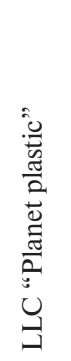 & 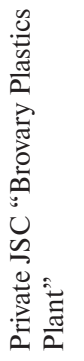 & 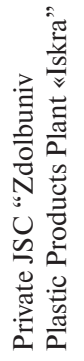 & 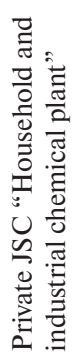 & 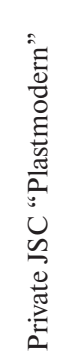 & 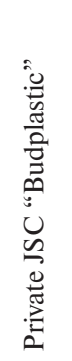 & 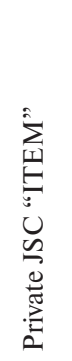 & 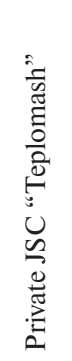 & 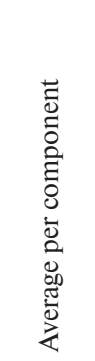 \\
\hline $\begin{array}{l}\text { The general level of organizational culture } \\
\text { of the enterprise }\end{array}$ & 0.32 & 0.27 & 0.25 & 0.26 & 0.24 & 0.24 & 0.24 & 0.28 & 0.39 & 0.2556 \\
\hline \multicolumn{11}{|c|}{ The level by the components: } \\
\hline professional & 0.41 & 0.39 & 0.32 & 0.34 & 0.38 & 0.35 & 0.3 & 0.32 & 0.37 & 0.3516 \\
\hline intellectual & 0.33 & 0.28 & 0.22 & 0.31 & 0.32 & 0.29 & 0.27 & 0.29 & 0.22 & 0.2785 \\
\hline information & 0.27 & 0.23 & 0.25 & 0.20 & 0.19 & 0.17 & 0.22 & 0.21 & 0.25 & 0.2190 \\
\hline social & 0.28 & 0.17 & 0.24 & 0.20 & 0.23 & 0.19 & 0.21 & 0.22 & 0.21 & 0.2110 \\
\hline legal and regulatory & 0.30 & 0.24 & 0.21 & 0.22 & 0.2 & 0.26 & 0.2 & 0.2 & 0.16 & 0.2179 \\
\hline technical and technological & 0.43 & 0.38 & 0.36 & 0.35 & 0.21 & 0.24 & 0.32 & 0.31 & 0.34 & 0.3198 \\
\hline communication & 0.32 & 0.28 & 0.22 & 0.21 & 0.25 & 0.23 & 0.25 & 0.19 & 0.28 & 0.2513 \\
\hline
\end{tabular}


JSC "Plastmodern" (0.24). Analyzing the data on this component, we should admit the fairly low level of technical and technological component of enterprises, which indicates the low efficiency of reproduction processes, namely the imperfection of the mechanisms of internal technology transfer; technical and technological backwardness of production and management processes; ineffective depreciation policy, etc.

The communicative component of the organizational culture of the enterprise has analysed indicators Public JSC "Ukrplastic" (0.32) and LLC "Planet plastic" (0.28), LLC "ITEM" (0.28), and the last positions are occupied by Private JSC "Zdolbuniv Plastic Products Plant "Iskra" (0.21) and Private JSC "Brovary Plastics Plant" (0.22). The essence of the communicative component is the exchange of information between employees. Analyzing the results of the study on the communicative component of the organizational culture of plastic manufacturers, one can see that the $\mathrm{H} 1$ of this research is not proved as there is the low level of communication between employees, departments and management, which negatively affects the activities of enterprises (reduced productivity, increased downtime). It is necessary to take a number of measures to improve communication in this industry, especially in view of the effects of the COVID-19 pandemic. So, the business culture reflection is not dominative within the organizational culture space of the plastic producers in Ukraine.

From the above calculations it can be concluded that in general all enterprises producing plastic products have the low overall level of organizational culture - less than $20 \%$ of the optimal level of organizational culture of the enterprise, and in some enterprises, it fluctuates at less than $10 \%$ to the optimal value. This indicates the need to develop organizational culture at the enterprises Public JSC "Ukrplastic", LLC "Planet plastic", Private JSC "Zdolbuniv Plastic Products Plant "Iskra" and the implementation of measures to form such a culture at the enterprises Private JSC "Brovary Plastics Plant", Private JSC "Household and industrial chemical plant", Private JSC "Plastmodern", Private JSC "Budplastic", LLC "ITEM", LLC "Teplomash".

The obtained results also proved the $\mathrm{H} 2$ of the research. The analyzed companies have the best results by the indicators of professional component and technical and technological component, which are closely connected with education and the plastic producers' cooperation with educational institutions, especially in the field of the developing common projects with young scientists and advanced training of employees.

Conclusions. Organizational culture should be considered as an important intangible resource that can significantly affect the efficiency of the firm and the formation of its market value. It regulates numerous corporate relations between business participants and their business activity, as it is realized in the process of cooperation of a business entity with various objects: people - employees, partners, consumers, public authorities, public opinion, and social groups. Thus, its main function is to create a sense of integrity of business counteragents on internal and external images of the entity in its relations with stakeholders. With this in mind, formation and development of favorable organizational culture is one of the main management tasks of the plastics production enterprise, in the solution of which it is mandatory to take into account the specifics of the industry.

The proposed improved method of the organizational culture evaluation based on binary logic is realized in this study regarding the following sets of indicators: professional, intellectual, informational, social, legal and regulatory, technical and technological, communicative.

The leader by all indicators and by the general indicator is Public JSC "Ukrplastic". The other enterprises of the industry occupy medium positions by the analyzed indicators. The study revealed the very low level of organizational culture of the companies producing plastic products in Ukraine, which negatively affects the current efficiency of these enterprises, and requires a set of measures for improving management of organizational culture of the enterprises in the industry.

The communication component does not take the leading positions among the other elements of the organizational culture of the plastic producers in Ukraine. It means that the working hypothesis $\mathrm{H} 1$ is not proved by the research. Otherwise, the received results emphasize the correctness of the working hypothesis $\mathrm{H} 2$ as the cooperation of business and education is better developed at those plastic producing enterprises, which have the better level of organizational culture.

Acknowledgement(s). The publication is realized within the young scientists' project "Realization of the young scientists' potential in integration of science, education, and business" (0120U102126) performed at the expense of the general fund of the state budget.

\section{References.}

1. Espasandín-Bustelo, F., Ganaza-Vargas, J., \& Diaz-Carrion, R. (2021). Employee happiness and corporate social responsibility: the role of organizational culture. Employee Relations, 43(3), 609-629. https://doi.org/10.1108/ER-07-2020-0343.

2. Schein, E. H., \& Schein, P.A. (2016). Organizational Culture and Leadership. $5^{\text {th }}$ Edition (The Jossey-Bass Business \& Management Series), Wiley. ISBN: 978-1-119-21204-1.

3. Sahaidak, M., Tepliuk, M., Zhurylo, V., Rudenko, N., \& Samko, O. (2021). Integrative Viewpoint for Implementing Sustainable Management Agricultural Business Excellence. TEM Journal, 10(1), 303-309. https://doi.org/10.18421/TEM101-38.

4. Olafsen, A. H., Nilsen, E. R., Smedsrud, S., \& Kamaric, D. (2021). Sustainable development through commitment to organizational change: the implications of organizational culture and individual readiness for change. Journal of Workplace Learning, 33(3), 180-196. https://doi.org/10.1108/JWL-05-2020-0093.

5. Alvi, H. A., Hanif, M., Adil, M. S., Ahmed, R. R., \& Vveinhardt, J. (2014). Impact of organizational culture on organizational commitment and job satisfaction. European Journal of Business and Management, 27(6), 30-39.

6. Ababneh, O. M.A. (2021). The impact of organizational culture archetypes on quality performance and total quality management: the role of employee engagement and individual values. International Journal of Quality \& Reliability Management, 38(6), 1387-1408. https://doi.org/10.1108/IJQRM-05-2020-0178.

7. Antoniuk, L., Britchenko, I., Polischuk, Y., Rudyk, N., Sybirianska, Y., \& Machashchik, P. (2018). Code of ethics for SMEs: substantiating the necessity and willingness to implement in Ukraine. Problems and Perspectives in Management, 16(3), 150-162. https://doi. org/10.21511/ppm.16(3).2018.12.

8. Semenets-Orlova, I., Klochko, A., Shkoda, T., Marusina, O., \& Tepliuk, M. (2021). Emotional intelligence as the basis for the development of organizational leadership during the Covid period (educational institution case). Estudios de Economía Aplicada, 39(5), 1-15. https://doi.org/10.25115/eea.v39i5.5074.

9. Iriqat, R. A. (2016). Organizational Commitment Role in Mediating the Impact of the Organizational Culture Dimensions on Job Satisfaction for MFIs' Employees in Palestine. International Journal of Business and Social Science, 7(5), 125-135.

10. Tran, Q. H. N. (2020). Organisational culture, leadership behaviour and job satisfaction in the Vietnam context. International Journal of Organizational Analysis, Advance online publication. https://doi. org/10.1108/IJOA-10-2019-1919.

11. Shorrock, S. T., \& Williams, C. A. (2016). Human factors and ergonomics methods in practice: three fundamental constraints. Theoretical Issues in Ergonomics Science, 17(5-6), 468-482. https://doi.org 110.1080/1463922X.2016.1155240.

12. Maciaszczyk, P., Dyba, M., \& Gernego, Iu. (2019). Strategies of human development in the context of global digital change. Economic Studies journal, 28(5), 10-24.

13. Riepina, I., Hrybinenko, O., Parieva, N., Parieva, O., Savenko, I., \& Durbalova, N. (2019). Quantity Assessment of the Risk of Investment Projects. International Journal of Recent Technology and Engineering, 8(3), 7256-7260. https://doi.org/10.35940/ijrte. C6338.098319.

14. Wolinska, J., \& Rakowska, A. (2014). Organizational culture and its role in business. The example of Polish culture. In Proceedings of International Conference "Human Capital without Borders: Knowledge and Learning for Quality of Life", 25-27 June 2014, (pp. 1089-1095). 
Slovenia: Portoroz. Retrieved from http://www.toknowpress.net/ ISBN/978-961-6914-09-3/papers/ML14-690.pdf.

15. Gautam, D. K., \& Basnet, D. (2020). Organizational culture for training transfer: the mediating role of motivation. International Journal of Organizational Analysis, Advance online publication. https:// doi.org/10.1108/IJOA-04-2020-2147.

16. Savych, O., \& Shkoda, T. (2020). Trends of air transportation market development in Ukraine. Innovative Marketing, 16(2), 29-42. https://doi.org/10.21511/im.16(2).2020.03.

17. Nitsenko, V., Chukurna, O., Mardani, A., Streimikis, J., Gerasymchuk, N., Golubkova, I., \& Levinska, T. (2019). Pricing in the Concept of Cognitive Marketing in the Context of Globalization: Theoretical, Methodological and Applied Aspects. Montenegrin Journal of Economics, 15(4), 131-147. https://doi.org/10.14254/18005845/2019.15-4.10.

18. Yatsenko, O. (2021). Polysubjectivity and Contextuality of the Ethical in Contemporary Digital Culture. Future Human Image, 15, 143-153. https://doi.org/10.29202/fhi/15/13.

19. Chebakova, T. (2020). Methods of the effective implementation of the organizational culture of Ukraine's enterprises. European Journal of Economics and Management, 6(1), 173-179.

20. Van Der Heiden, P., Pohl, C., Bin Mansor, S., \& Van Genderen, J. (2015). The role of education and training in absorptive capacity of international technology transfer in the aerospace sector. Progress in Aerospace Sciences, 76, 42-54. https://doi.org/10.1016/j.paerosci.2015.05.003.

\section{Організаційна культура у співпраці бізнесу та освіти в Україні}

\author{
М.А. Теплюк ${ }^{1}$, Т. Н. Шкода ${ }^{1}$, В. П. Кукоба ${ }^{1}$, \\ Т. О. Чебакова ${ }^{1}$, С. В. Петровська ${ }^{2}$
}

1 - Київський національний економічний університет імені В.Гетьмана, м. Київ, Україна, e-mail: mteplyuk@ gmail.com

2 - Національний авіаційний університет, м. Київ, Україна
Мета. Удосконалити методику оцінки організаційної культури для прийняття управлінських рішень у співпраці бізнесу та освіти.

Методика. Дослідження базується на даних провідних підприємств із виробництва пластмас в Україні за період 2015-2019 років. Застосовуючи метод бінарної логіки для цілей оцінки запропонованих компонентів організаційної культури підприємств (інтелектуальної, техніко-технологічної, соціальної, правової й регуляторної, професійної, комунікативної, інформаційної), рівні цієї культури у виробників пластмас визначаються в математичні терміни.

Результати. На основі узагальнення результатів теоретичного дослідження економічної сутності організаційної культури підприємства визначені ії ключові складові та основні параметри, що характеризують їх. ПАТ «Укрпластик» визнано провідною компанією, що виготовляє вироби із пластмас в Україні, з найвищими показниками в організаційній культурі за окремими компонентами підприємства. Інші аналізовані компанії мають середній рівень показників організаційної культури.

Наукова новизна. Дослідження сприяє вивченню організаційної культури, особливо в перспективі його використання в якості інструменту співпраці між українськими виробниками пластмас - представниками бізнесу та освітнім сектором.

Практична значимість. Результати дослідження можуть бути використані практиками, науковцями, державними службовцями (Міністерство освіти і науки України та його структурні підрозділи, органи місцевого самоврядування в галузі освіти та науки) для моніторингу розвитку інформаційної економіки.

Ключові слова: організаційна культура, кооперація, бізнес, освіта, виробники пластмас, Україна

Recommended for publication by I. Repina, Doctor of Economic Sciences. The manuscript was submitted 25.01.21. 